\title{
Facile Synthesis of Silica Coated Magnetic Nanoparticles via Green Microwave-Solventless Technique for Purification of Water from Toxic Heavy Metals
}

\section{Salwa A Ahmed', Karima M Zaki and Ezzat M Soliman}

Chemistry Department, Faculty of Science, Minia University, Minia, Egypt

\begin{abstract}
Silica coated magnetic nanoparticles (SCMNPs) were synthesized via microwave technique and used for removal of $\mathrm{Cd}(\mathrm{II}), \mathrm{Zn}(\mathrm{II})$, and $\mathrm{Co}(\mathrm{II})$ ions from water samples. These synthesized nanoparticles were characterized using Fourier Transforming Infrared (FT-IR), X-Ray Diffraction (XRD), Scanning electron microscopy (SEM), and Transmission electron microscopy (TEM). Effects of variables such as pH, contact time, weight of nano-adsorbent, and concentration of the target metal ion on metal uptake capacity have been studied to obtain the optimum conditions. The results recorded metal uptake values to be 2.314, 1.950, $1.780 \mathrm{mmol} / \mathrm{g}$ for $\mathrm{Cd}(\mathrm{II}), \mathrm{Zn}(\mathrm{II})$, and Co(II), respectively. The equilibrium data were fitted well with Freundlich model. Kinetic study showed well agreement with the pseudo-second-order one. SCMNPs has been applied to remove $\mathrm{Cd}(\mathrm{II}), \mathrm{Zn}(\mathrm{II})$, and $\mathrm{Co}$ (II) from real water samples with quantitative recovery. Finally, regeneration of SCMNPs reached 10 times with the same efficiency; and also found to be very stable under acidic conditions.
\end{abstract}

\section{Keywords}

Heavy metals, Isotherm, Magnetite, Microwave, Nano-adsorbent, Removal, Silica

\section{Introduction}

Nano-adsorbents are nanoscale particles or nanocomposites from organic/inorganic materials that have high affinity to absorb substances due to small size and high surface area [1]. They are distinguished by their large surface area and having unique properties and potential applications, especially in water treatment [2]. However, the removal of nano-adsorbent from water solutions is difficult for the small size of these particles. So, magnetic nanoparticles overcome this defect by removing these nanoparticles (NPs) and hazardous elements adsorbed using an external magnet [3]. The magnetic separation method is effective and has little cost in many areas such as environmental applications, large-scale water purification, sewage treatment, nuclear industry, food production, pharmaceutical and biochemical activities [4]. Iron oxide is one of the most important magnetic nano-sized materials. It has a major role in many areas of chemistry and materials science, in addition to the appropriate magnetic properties, cheapness, and low toxicity [5]. Unfortunately, uncoated magnetic nano-sized iron-oxides have many defects. They are likely to agglomerate in aqueous solutions accordingly,

*Corresponding author: Prof. Dr. Salwa A Ahmed, Chemistry Department, Faculty of Science, Minia University, Minia, Egypt

Accepted: June 04, 2020; Published: June 06, 2020

Copyright: (c) 2020 Ahmed SA, et al. This is an open-access article distributed under the terms of the Creative Commons Attribution License, which permits unrestricted use, distribution, and reproduction in any medium, provided the original author and source are credited.

Ahmed et al. Int J Nanoparticles Nanotech 2020, 6:036

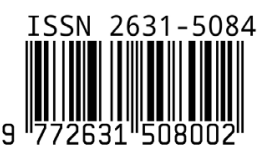


magnetic properties change and biodegrade in biological systems, it was also found that the bare magnetic nano-adsorbent were exposed to oxidation and loss of its magnetic properties at $\mathrm{pH}$ lower than 4 [3]. So, coating of magnetic NPs with silica is a commonly used procedure to obtain magnetic sorbents; this is due to silica stability and versatility of its surface modification [6]. Silica coated magnetic nanoparticles with a magnetic core and a silica shell has the advantages of both materials with no apparent effect on magnetic properties that characterize the nano-magnetite [3]. Using of this magnetic nano-adsorbent for removal of pollutants from water continues to progress nowadays. Heavy metals are considered to be the most hazardous pollutants in the environment [7]. Recently, heavy metals have spread in the environment as a result of various human activities such as metal plating facilities [8], metal finishing, welding and alloy manufacturing [9], mining, fossil fuel combustion and poor sewerage systems, fertilizer industries tanneries, batteries, paper industries and pesticides, etc. Waste water containing heavy metals is often discharged directly or indirectly into the environment, especially in developing countries $[8,9]$. In living organisms, heavy metals - differ from some organic pollutants - become toxic and non-metabolized when their concentration exceeds the tolerance limit, so the metal bioaccumulates in the soft tissues. Heavy metals can enter the human body through water, food, air or through skin absorption [10]. Furthermore, providing safe drinking water is the key to protecting human health. The presence of these heavy metals, even at low concentrations, is a threat and a real danger to the sources of clean water [11]. About $25 \%$ of recent human diseases occur due to long-term exposure to environmental pollutants; this is what has been appreciated by the World Health Organization (WHO) [12]. For example, zinc is one of the most hazardous pollutants that affect human health, among the symptoms of zinc poisoning there are nausea, stomachache, dehydration, electrolyte imbalance, dizziness and in coordination in muscles [13]. Cobalt also has significant health effects, cobalt poisoning causes heart damage causing heart failure, asthma, damage of the thyroid and liver, may also cause genetic mutations, and exposure to ionized radiation increases risk of developing cancer in living cells [14]. Furthermore, cadmium poisoning causes serious diseases, such as pulmonary fibrosis, renal tubular abnormalities, chronic renal injury and an increased risk of cancer [15]. Therefore there is an urgent need to remove and identify those heavy metals from the environment [9].

There are many techniques and processes that have been used to remove heavy metals from water such as precipitation, ion exchange, evaporation, electrochemical treatments, membrane filtration, flocculation, reverse osmosis, evaporation, flotation, and oxidation. Most of these techniques have their disadvantages $[2,11]$. For example, precipitation is ineffective when metal ion concentration is low, is not economical and can produce large amount of sludge to be treated with great difficulties. Ion exchangers need to be renewed when they are exhausted and the regeneration can cause serious secondary pollution, and it is expensive. Electrochemical treatments, flocculation and membrane filtration is a high cost techniques, process complexity, membrane fouling and low permeate flux. On the contrary, adsorption is an ideal technique to remove toxic pollutants from water for its simplicity, high efficiency, ease of operation, regeneration characteristics [3], and can remove heavy metals found in water at low concentrations [16]. Fortunately, the evolution of nanotechnology has highlighted this issue [2]. Many researchers used silica coated magnetite and attended it by many methods. From these methods One-Pot Solvothermal process which need very high temperatures and takes about 12 hours and need solvents [17]. Also, among SCMNPS preparation methods there are electrochemical and sol gel methods which are complicated and expensive techniques [18].

In our current study, the silica coated magnetic nanoparticles (SCMNPs) were synthesized using simple and fast household microwave synthesis technique with only a few drops of water (without need to use harmful solvent). The structural, physical and chemical properties of SCMNPs were analyzed; its efficiency has been tested in removing of $\mathrm{Cd}(\mathrm{II}), \mathrm{Zn}(\mathrm{II})$, and $\mathrm{Co}(\mathrm{II})$ ions from aqueous solutions under different variables. In addition, the possibility of reusing SCMNPs has been carried out more than 10 consecutive times with the same efficiency and its high stability has been recorded at acidic medium. Finally, water samples from different sources were purified from heavy metals as an application of using this nano-adsorbent in the environment. 


\section{Experimental}

\section{Materials}

Ferric chloride $\left(\mathrm{FeCl}_{3} \cdot 6 \mathrm{H}_{2} \mathrm{O}\right)$ with $98 \%$ purity and ferrous sulphate $\left(\mathrm{FeSO}_{4} .7 \mathrm{H}_{2} \mathrm{O}\right)$ with $98 \%$ purity were purchased from Oxford, India. The silica gel used was of TLC grade (70-230 mesh size and 60 $\AA$ pore diameter), purchased from Woelm pharm, Eschwege, Germany. 0.1M of stock acidified solutions of $\mathrm{CdCl}_{2} \cdot 2 \mathrm{H}_{2} \mathrm{O}, \mathrm{ZnCl}_{2} \cdot 2 \mathrm{H}_{2} \mathrm{O}$, and $\mathrm{CoCl}_{2} \cdot 2 \mathrm{H}_{2} \mathrm{O}$ were prepared by dissolving 13.629, 20.132, and $15.5 \mathrm{~g}$, respectively in 1.0 liter measuring flask using double distilled water (DDW) (a small amount of $\mathrm{HCl}(1 \mathrm{M})$ was added for each metal ion solution to avoid the hydrolysis). These metal salts were of analytical grade purchased from Aldrich (USA), BDH (England) or Prolabo (Egypt). Methylthymol blue and xylenol orange used as indicators for complexometric EDTA titration. $\mathrm{HCl}$ and $\mathrm{NaOH}$ used for justifying the $\mathrm{pH}$ values were purchased from Aldrich chemical Co., USA. Water samples including: Nile River water (NRW), ground water (GW) were collected from Minia governorate, Egypt, drinking tap water (DTW) from Minia university, and sea water (SW) was collected from Alexandria governorate, Egypt.

\section{Instruments}

The FT-IR-spectra of (SCMNPs) was recorded by Shimadzu Affinity A, FT-IR spectrophotometer (Japan) using $\mathrm{KBr}$ pellets and expressed as $U_{\text {max }} \mathrm{cm}^{-1}$. A Fisher Scientific Accumet pH-meter (Model 825) (Germany) calibrated against two standard buffer solutions at $\mathrm{pH} 4.0$ and 9.2 were used for all $\mathrm{pH}$ measurements. Atomic absorption measurements for measuring concentrations of metal ions were performed with Aquanova-Genway spectrometry (UK). Wrist Action mechanical shaker Model 75 (manufactured by Burrell Corp., Pittsburgh, PA, USA) was used for the shaking process. Microwave oven (KOR-131G, Korea) emitting $2450 \mathrm{MHz}$, voltage: $230 \mathrm{~V}$, frequency: $50 \mathrm{~Hz}$, input power: $1650 \mathrm{~W}$, energy output: $1100 \mathrm{~W}$ was used for the synthesis of the novel SCMNPs. X-ray Diffraction (XRD) analysis for proving the crystal phase of the magnetic composite was carried out by JEOL X-ray diffractometer system, model JDX-9C specification (Japan). The size, morphology and structure of nano-adsorbent were characterized by JEOL GEM-1010 transmission electron microscope (TEM) at $70 \mathrm{kV}$ (Japan) at the Regional Center of Mycology and Biotechnology,
Al-Azhar University, Cairo, Egypt. The micrographs of prepared particles were obtained using scanning electron microscopy (SEM) (model: JSM-5500 LV; JEOL Ltd -Japan) by using high vaccum mode at the Regional Center of Mycology and biotechnology, Al-Azhar university, Cairo, Egypt.

\section{Synthesis of the magnetic nano-adsorbent}

Preparation of magnetic nanoparticles: Magnetic nanoparticles were prepared by the co-precipitation method, by slow addition of $5 \mathrm{M} \mathrm{NaOH}$ solution into a mixed solution of $0.25 \mathrm{M} \mathrm{FeSO}_{4} \cdot 7 \mathrm{H}_{2} \mathrm{O}$ and $0.5 \mathrm{M} \mathrm{FeCl}_{3} \bullet 6 \mathrm{H}_{2} \mathrm{O}$ till obtaining $\mathrm{pH} 11$, at room temperature. The magnetite particles thus formed were left to settle, then magnetically separated from the supernatant where they thoroughly washed with doubly distilled water till reaching neutral medium $[19,20]$. Finally, they collected and dried in an oven at $60^{\circ} \mathrm{C}$. The $\mathrm{Fe}_{3} \mathrm{O}_{4}$. MNPs thus produced using this method was dense, dark brown and magnetic with a particle size in range 13.3-29.2 $\mathrm{nm}$.

Silica coated magnetic nanoparticles: An advanced method has been developed for this purpose, where a solid - solid interaction is performed under solvent-less microwave condition. Thus, $\mathrm{Fe}_{3} \mathrm{O}_{4}$. MNPs were mixed with silica in weight/ weight ratios $(w / w=1: 1)$. These mixtures were individually grinded using mortar of agate, wetted with drops of distilled water and then microwaved at actual power $200 \mathrm{w}$ for $20 \mathrm{~min}$. The produced nano-adsorbents were dry and homogeneous with color of dark brown of silica coated magnetic nanoparticles (SCMNPs) see graphical Scheme 1.

\section{Parameters affecting metal uptake capacity}

The metal uptake capacity of SCMNPs towards $\mathrm{Zn}(\mathrm{II}), \mathrm{Cd}(\mathrm{II})$, and $\mathrm{Co}(\mathrm{II})$ ions were determined in triplicate under static conditions by the batch equilibrium technique. In which $25 \mathrm{mg}$ of SCMNPs were added to $1 \mathrm{ml}$ of $0.1 \mathrm{M}$ of metal ion solution at $\mathrm{pH}$ range of 1.0 to 6.0 , except for $\mathrm{Zn}(\mathrm{II})$, where the $\mathrm{pH}$ used at 1.0 to 8.0; the total volume was completed to $50 \mathrm{ml}$ by DDW in a $100 \mathrm{ml}$ measuring flask, for $\mathrm{pH}$ adjustment, solutions of $0.1 \mathrm{M} \mathrm{HCl}$ and $0.1 \mathrm{M} \mathrm{NaOH}$ were used. The mixture was mechanically shaken for $10 \mathrm{~min}$ at room temperature to reach equilibrium. Then, the nano-adsorbent was separated by an external magnet and washed with DDW; the unretained metal ion in the filtrate was determined by complexometric EDTA titration. The equation of 
metal uptake capacity could be obtained as follow:

$$
\mathrm{Q}_{\mathrm{e}}=\left(\mathrm{C}_{\mathrm{o}}-\mathrm{C}_{\mathrm{e}}\right) \mathrm{V} / \mathrm{m}
$$

Where, $\mathrm{C}_{\mathrm{o}^{\prime}}$ and $\mathrm{C}_{\mathrm{e}}$ are initial concentration of metal ion $(\mathrm{mmol} / \mathrm{mL})$ and the equilibrium concentration of unsorped metal ions in the decanted solution $(\mathrm{mmol} / \mathrm{mL})$, respectively, $V$ is the volume of solution $(\mathrm{mL})$ and $\mathrm{m}$ is the nanocomposite mass in grams (g). Finally, $Q_{e}$ is metal uptake capacity (mmol/g) [21].

Moreover the effect of contact time on metal uptake was determined under the same conditions for different equilibrium periods $(2,5,10,20$, and $30 \mathrm{~min}$ ) at the $\mathrm{pH}$ of the highest metal ion uptake (optimum $\mathrm{pH}$ value). Effect of weight was determined for different weights $(10,25,35$, and $50 \mathrm{mg})$ of nano-adsorbent, and effect of concentration was determined for different concentrations of metal ion ranging from $2 \times 10^{-4}$ to $2 \times 10^{-3} \mathrm{M}$.

\section{Stability studies (Effect of medium)}

The study of prolonged medium effects on the adequacy of SCMNPs is important from practical application point of view. It was investigated under static conditions, different concentrations $(0.1$, 0.3 , and $0.5 \mathrm{M}$ ) of $\mathrm{HCl}$ prepared, mixed with definite weights of nano-adsorbent and shaking the mixture for $30 \mathrm{~min}$. To increase the emphasis on the nano-adsorbent stability, another definite weight was impregnate with $0.1 \mathrm{M} \mathrm{HCl}$ overnight. The treated SCMNPs was filtered, washed with DDW and dried at $60^{\circ} \mathrm{C}$ for $6 \mathrm{~h}$. Then, evaluate the metal ion sorption capacity at the optimum $\mathrm{pH}$ values using the batch technique under the same conditions as previously described. Finally, the results have been compared with the standard untreated one to follow the hydrolysis of the nano-adsorbent.

\section{Regeneration of the nano-adsorbent}

To investigate the extent to which SCMNPs could be used more than once to extract the metal after first use, ethylenediaminetetraacetic acid (EDTA) was used as a strong complexing agent to recover the metal from the surface of the SCMNPs by a batch recycling process. Thus, $100 \mathrm{mg}$ of SCMNPs after adsorption of metal ion at optimum $\mathrm{pH}$ values was mixed with excess of 0.1M EDTA solution. Then, they are shaken for an hour, filtered, washed with DDW many times and dried at $60^{\circ} \mathrm{C}$ for $6 \mathrm{~h}$ to evaluate the ability of SCMNPs to be reused.

\section{Result and Discussion}

\section{Characterization of silica coated magnetic na- no-adsorbent}

FT-IR analysis: The FT-IR spectra of silica, $\mathrm{Fe}_{3} \mathrm{O}_{4^{\prime}}$ and $\mathrm{Fe}_{3} \mathrm{O}_{4} / \mathrm{SiO}_{2}$, are shown in Figure 1 for determination of variation frequency changes in the range of $4000-400 \mathrm{~cm}^{-1}$. (Figure 1a) illustrates the spectrum of silica gel in which appear a strong and sharp peak of Si-O bond at $1100 \mathrm{~cm}^{-1}$, the peaks at 480 $\mathrm{cm}^{-1}$ are ascribed to the $\mathrm{Si}-\mathrm{O}-\mathrm{Si}$ bending vibration, also a strong peak of the silanol groups appear at $3444.82 \mathrm{~cm}^{-1}$. The characteristic wavenumbers of 625 and $575 \mathrm{~cm}^{-1}$ corresponds to the Fe-O bonds, which is reported to belong to bulk magnetite, (Figure $1 \mathrm{~b}$ ). Finally, the FT-IR spectrum of SCMNPs as shown in (Figure 1c) was measured to demonstrate the coverage of the surface of magnetite by silica gel. The deposition of silica network on the magnetite surface by Fe-O-Si bonds was confirmed by obtaining relevant FT-IR spectrum. The corresponding absorption band cannot be seen in the FT-IR spectrum because it appears at around $580 \mathrm{~cm}^{-1}$ and inevitably overlaps with the $\mathrm{Fe}-\mathrm{O}$ vibration of magnetite, it also shows appearing of peaks of bulk magnetite $\left(\mathrm{Fe}_{3} \mathrm{O}_{4}\right)$ stretching vibration with a slight deviation to right. On the other hand, the strong and sharp peaks appeared and shifted at approximate 1000.43 and $3412.86 \mathrm{~cm}^{-1}$ belongs to $\mathrm{Si}-\mathrm{O}$ bond and silanol groups of silica gel, respectively. The final product which obtained as dense, dark brown and has magnetic properties implying complete coverage of the surface of magnetite core by a shell of silica gel $[22,23]$.

X-ray diffraction, Scanning electron microscope (SEM), and transmission electron microscope (TEM): XRD patterns of silica, magnetite, and SCMNPs were obtained in Figure 2. The XRD peaks of magnetite show characteristic diffraction line at $2 \theta$ range of $25-65^{\circ}$ as shown in Figure 2a. Peaks of silica appear about $2 \theta$ range of $8-27^{\circ}$, (Figure $2 b$ ). Finally by studying the XRD of SCMNPs, as shown in Figure 2c, new diffraction lines were observed at $2 \theta$ range of $15-64^{\circ}$, shows the peaks for SCMNPs with differences in the intensity and shape of the peaks. These changing in diffraction lines are favor to prove immobilization of the magnetite core with a silica shell.

The morphological shape of the silica magnetite surface was analyzed by using scanning electron microscope (SEM) as illustrated in Figure 3. The image contains large particles with a rough surface 

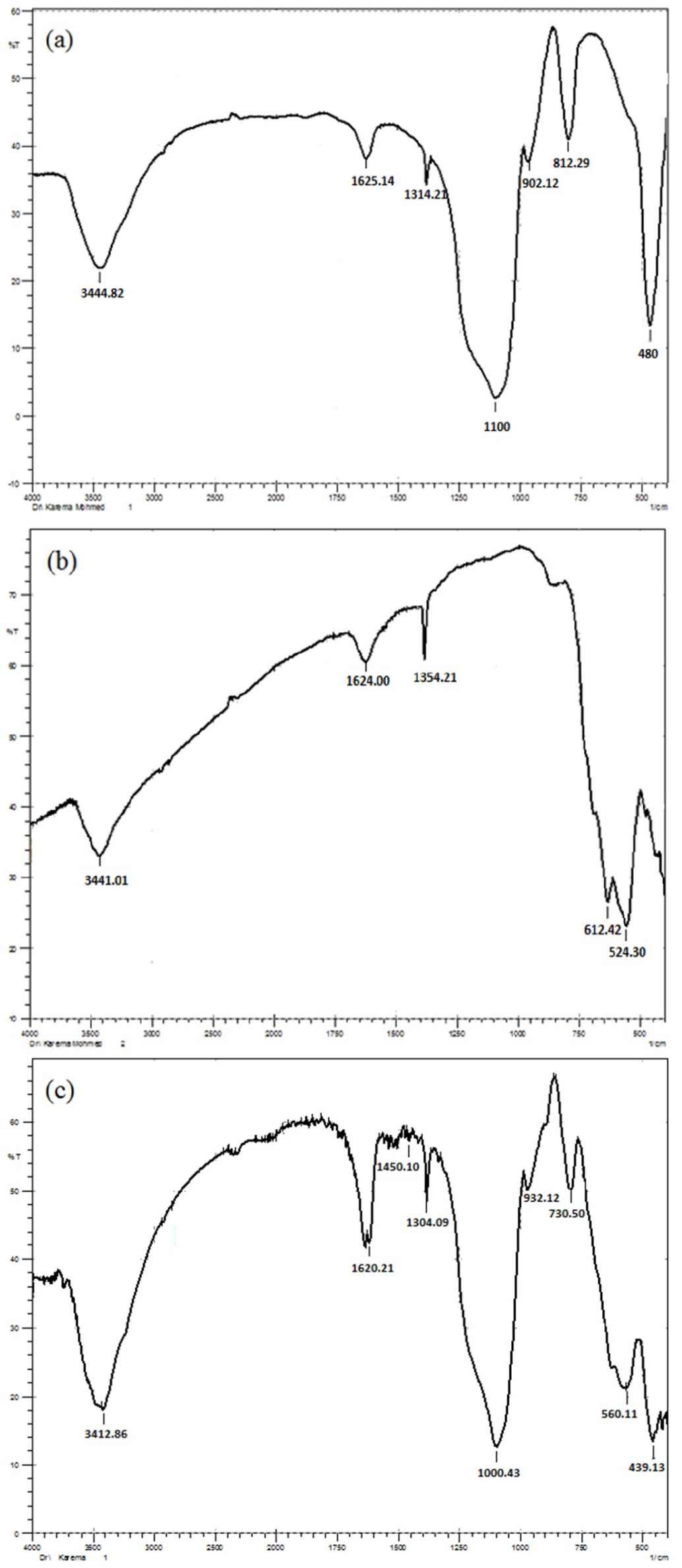

Figure 1: FT-IR spectra of a) Silica; b) $\mathrm{Fe}_{3} \mathrm{O}_{4} \cdot M N P s$, and c) SCMNPS. 

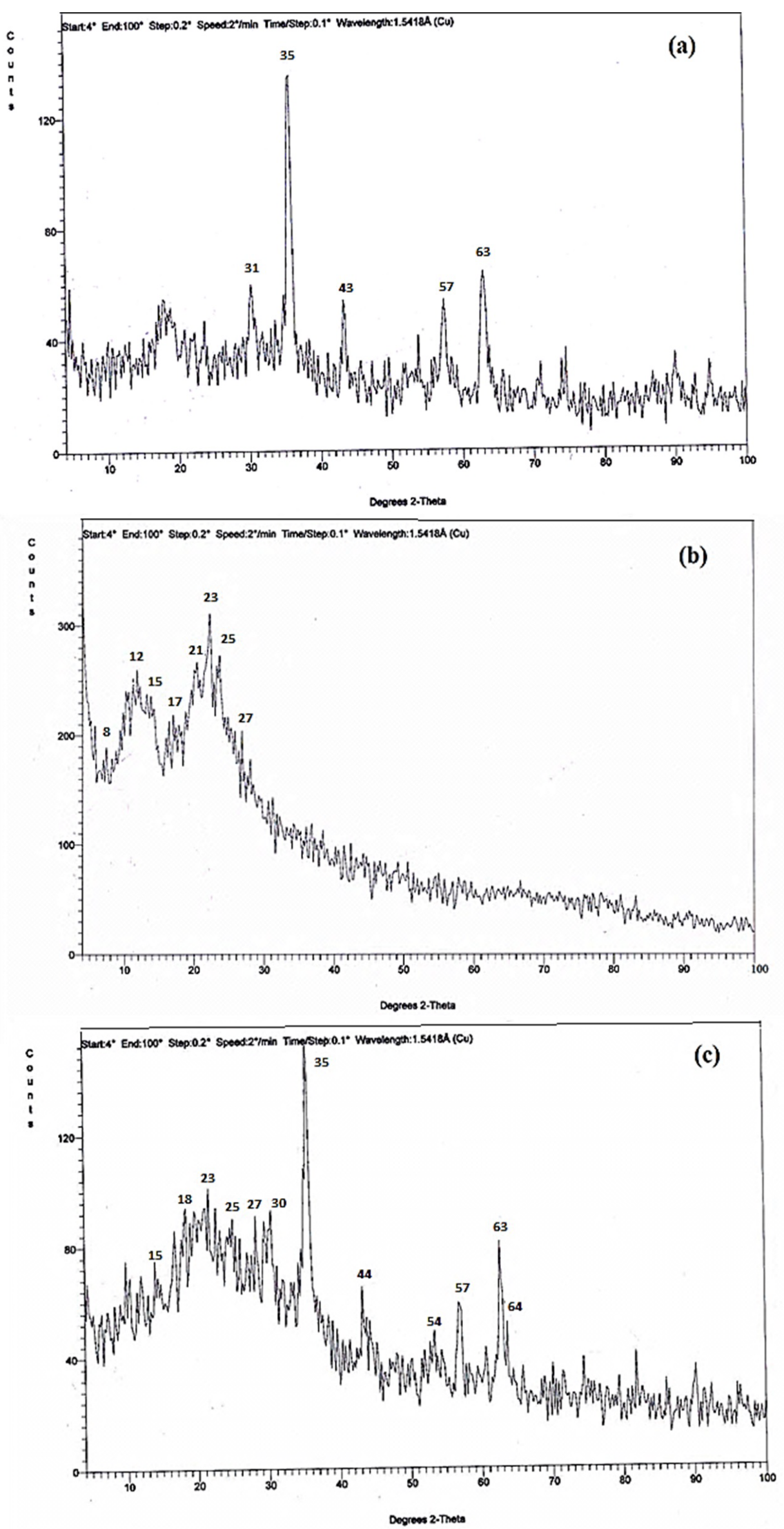

Figure 2: X-ray diffraction for a) $\mathrm{Fe}_{3} \mathrm{O}_{4}$.MNPs; b) Silica, and c) SCMNPs. 


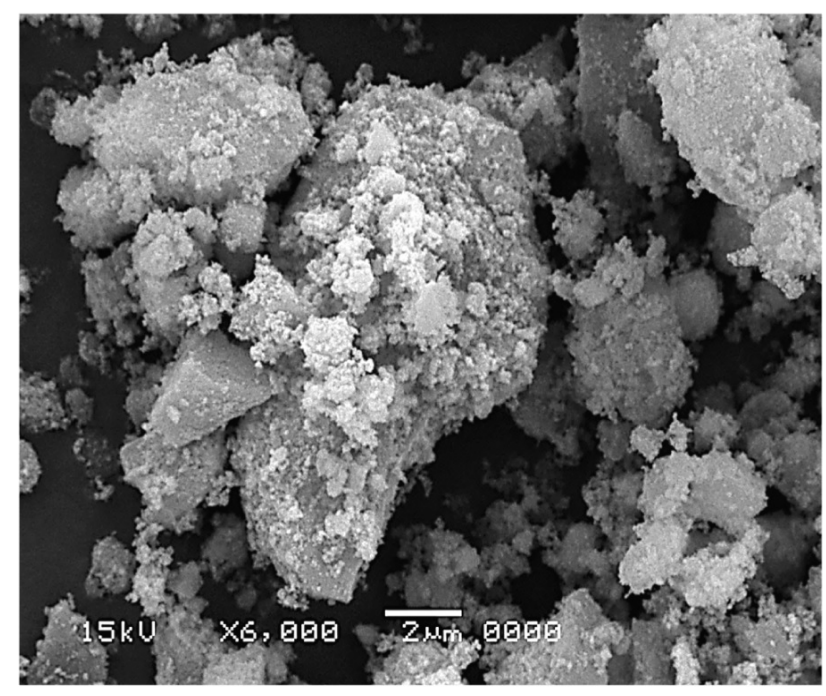

Figure 3: SEM images of SCMNPs.

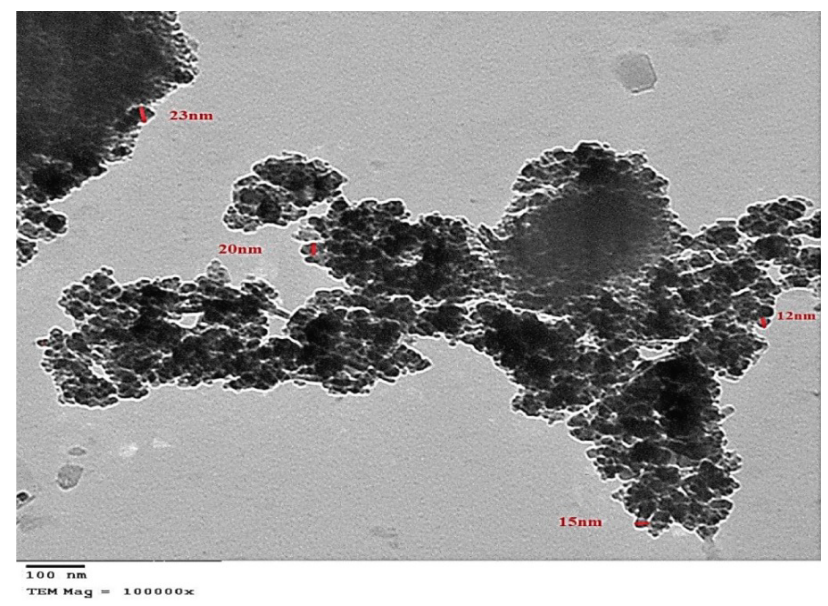

Figure 4: TEM images of SCMNPS.

and good homogeneity in the distribution with respect to particle size and shape. These large particles represent an important factor in facilitating the process of mass transfer rate of metal ions to be adsorbed on the surface of SCMNPs, and so get better adsorption capacity.

The size and structure of SCMNPs were characterized using TEM micrographs, Figure 4. Practical experiments have demonstrated the presence of spherical particles, and as observed that there are black magnetite cores and a thin shell of silica coating it. Molecule diameter is at the range of 11.7$24.81 \mathrm{~nm}$ with the mean size of $16.93 \mathrm{~nm}$.

\section{Adsorption studies}

Effect of pH: The study of the effect of $\mathrm{pH}$ of the solution has been found to have a significant impact on metal adsorption on the surface of SCMNPs. The

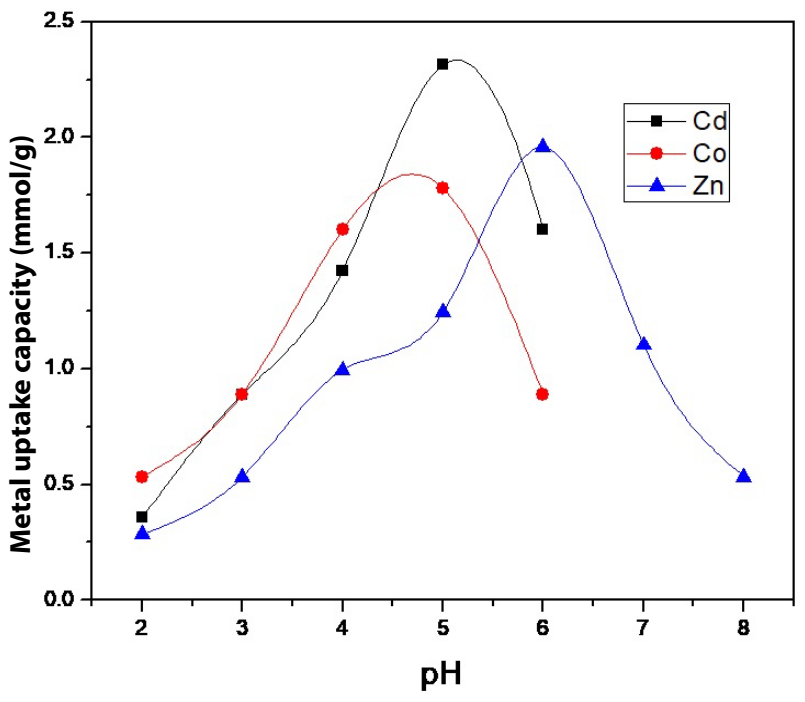

Figure 5: Effect of $\mathrm{pH}$ on metal uptake capacity of $\mathrm{Cd}(\mathrm{II}), \mathrm{Co}(\mathrm{II})$, and $\mathrm{Zn}(\mathrm{II})$ using SCMNPs.

$\mathrm{pH}$ effect was studied over the $\mathrm{pH}$ range from 1.0 to 8.0 by the batch equilibrium technique under static conditions. As shown in Figure 5, there is low efficiency toward the extraction of heavy metal at low $\mathrm{pH}$ values; there is a large amount of hydrogen ions so a competition occurs between metal ions and hydrogen ions on the binding sites, resulting in decrease of metal ions binding. By increasing the value of $\mathrm{pH}$ the competition become weaker so metal uptake capacity increase until it reach its optimum value at 5.0 for $\mathrm{Cd}(\mathrm{II})$ and $\mathrm{Co}(\mathrm{II})$, and 6.0 for $\mathrm{Zn}(\mathrm{II})$. The values of metal uptake capacity at the optimum $\mathrm{pH}$ for $\mathrm{Cd}(\mathrm{II}), \mathrm{Zn}(\mathrm{II})$, and $\mathrm{Co}(\mathrm{II})$ were 2.314, 1.952, and $1.780 \mathrm{mmol} / \mathrm{g}$, respectively. By increasing the $\mathrm{pH}$ value more than 6.0, metal uptake capacity go back again to decline due to the presence of excess amount of hydroxide ion. The predominant metal species at $\mathrm{pH}$ between 2.0 and 7.0 are positively charged $\left[\mathrm{M}^{\mathrm{n}+}\right.$ and $\left.\mathrm{M}(\mathrm{OH})^{(\mathrm{n}-1)+}\right]$, therefore, uptake of metals may proceed through $\mathrm{Mn}^{+}$exchange process with acidic sites $\mathrm{H}^{+}$, complexing with functional groups and/or chelation [24]. Finally, the affinity of SCMNPs for binding to the studied heavy metal ions can be arranged based on their uptake values according to the following order: $\mathrm{Cd}(\mathrm{II})>\mathrm{Zn}(\mathrm{II})>$ Co(II).

Effect of contact time: The effect of contact time was studied over a variety of times $(2,5,10$, 20 , and $30 \mathrm{~min}$ ) at the optimum $\mathrm{pH}$ value for each studied metal. Determination of the equilibrium contact time is an important parameter not only for the adsorption process, but also for the oper- 


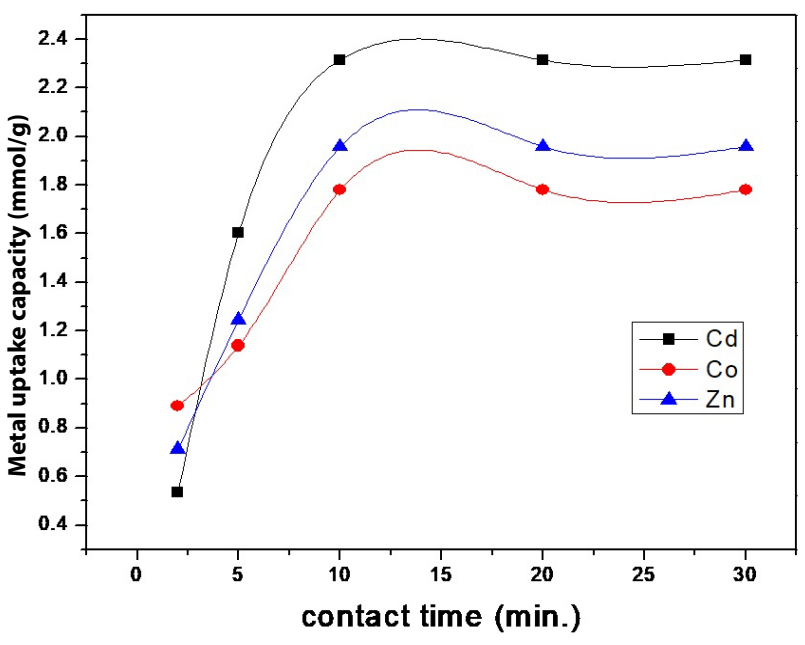

Figure 6: Effect of contact time on metal uptake capacity of $\mathrm{Cd}(\mathrm{II}), \mathrm{Co}(\mathrm{II})$, and $\mathrm{Zn}(\mathrm{II})$ using SCMNPs.

ational cost, Figure 6. It was clearly indicated that the rate of adsorption was very fast and the equilibrium was reached within 10 min of contact time and then reached to a saturation level. The adsorption process was fast at the beginning stages because of the availability of vacant binding sites on SCMNPs composite as the time passed; these active sites became more reacted and covered with metal ions, which restricted further binding of ions. The short equilibrium time (10 $\mathrm{min}$ ) provides an economic advantage for extensive application because it means less energy consumption and reduction of production cost [25]. Therefore, metal uptake capacities at $10 \mathrm{~min}$ (optimum time) for $\mathrm{Cd}(\mathrm{II}), \mathrm{Zn}(\mathrm{II})$, and Co(II) were 2.314, 1.952, and $1.870 \mathrm{mmol} / \mathrm{g}$, respectively.

A kinetic model was created to study the mechanism of removal of metals and its potential rate-controlling steps to analyze the experimental data. The sorption kinetic data was analyzed in terms of pseudo-first-order and pseudo-second-order sorption equations. The equation of the pseudo-first-order is shown below:

$$
\frac{d q_{t}}{d t}=k_{1}\left(q_{e}-q_{t}\right)
$$

Where, $q_{t}(\mathrm{mmol} / \mathrm{g})$ refer to the amount of sorption at time $t(\mathrm{~min}), \mathrm{q}_{\mathrm{e}}(\mathrm{mmol} / \mathrm{g})$ is the amount of sorption at equilibrium, and $\mathrm{k}_{1}\left(\mathrm{~min}^{-1}\right)$ is the rate constant of the pseudo-first-order sorption. After doing integration and at the conditions of $q_{t}=0$ at $t$ $=0$ and $q_{t}=q_{t}$ at $t=t$, Eq. (2) becomes:

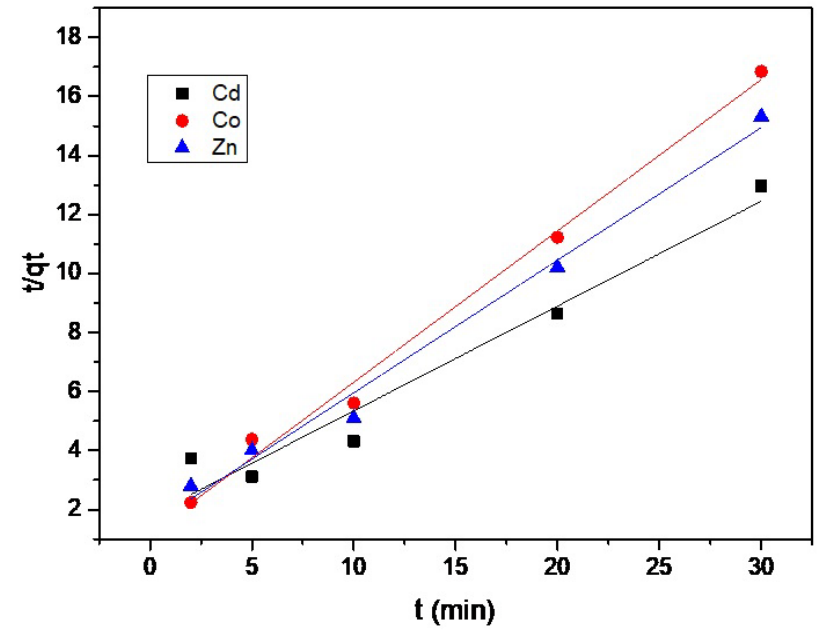

Figure 7: Pseudo-second-order kinetic plot for the adsorption capacity of $\mathrm{Cd}(\mathrm{II}), \mathrm{Zn}(\mathrm{II})$, and $\mathrm{Co}(\mathrm{II})$ using SCMNPs.

$$
\log \left(\mathrm{q}_{\mathrm{e}}-\mathrm{q}_{\mathrm{t}}\right)=\log \mathrm{q}_{\mathrm{e}}-\left(\frac{\mathrm{k}_{1}}{2.303}\right) \mathrm{t}
$$

But this model cannot be applied because there is no correlation with the experimental data, so it is not appropriate to describe the entire process. So, the adsorption kinetic data analyzed also in terms of pseudo-second-order sorption equation which is shown below:

$$
\frac{\mathrm{dq}_{\mathrm{e}}}{\mathrm{dt}}=\mathrm{k}_{2}\left(\mathrm{q}_{\mathrm{e}}-\mathrm{q}_{\mathrm{t}}\right)^{2}
$$

Here, $\mathrm{k}_{2}(\mathrm{~g} / \mathrm{mmol} / \mathrm{min})$ is the rate constant. By integration of this equation and application at conditions of $\mathrm{q}_{\mathrm{t}}=0$ at $\mathrm{t}=0$ and $\mathrm{q}_{\mathrm{t}}=\mathrm{q}_{\mathrm{t}}$ at $\mathrm{t}=\mathrm{t}$, Eq. (4) becomes:

$$
\frac{1}{\mathrm{q}_{\mathrm{e}}}-\mathrm{q}_{\mathrm{t}}=\frac{1}{\mathrm{q}_{\mathrm{e}}}+\mathrm{k}_{2} \mathrm{t}
$$

By rearrangement of Eq. (5) to give the linear form as follows:

$$
\frac{\mathrm{t}}{\mathrm{q}_{\mathrm{t}}}=\frac{1}{\mathrm{v}_{\mathrm{o}}}+\left(\frac{1}{\mathrm{q}_{\mathrm{e}}}\right) \mathrm{t}
$$

Where, $v_{o}=\mathrm{kq}_{\mathrm{e}}^{2}\left(\mathrm{mmol} \mathrm{g}^{-1} \mathrm{~min}^{-1}\right)$ is the initial sorption rate, $\mathrm{k}\left(\mathrm{g} \mathrm{mmol}^{-1} \mathrm{~min}^{-1}\right)$ is the rate constant of sorption, $\mathrm{q}_{\mathrm{e}}\left(\mathrm{mmol} \mathrm{g}^{-1}\right)$ is the amount of metal sorbed at equilibrium, and $\mathrm{q}_{\mathrm{e}}\left(\mathrm{mmol} \mathrm{g}^{-1}\right)$ is the amount of metal ion sorbed at time $t(\mathrm{~min})$. By plotting $t / q_{t}$ versus $t, v_{o}$ and $q_{e}$ can be obtained from the intercept and slope, respectively as shown in Figure 7 . They were calculated to find that their values were: $v_{o}=2.272 \mathrm{mmol} \mathrm{g}^{-1} \mathrm{~min}^{-1}, \mathrm{q}_{\mathrm{e}}=2.380$ 


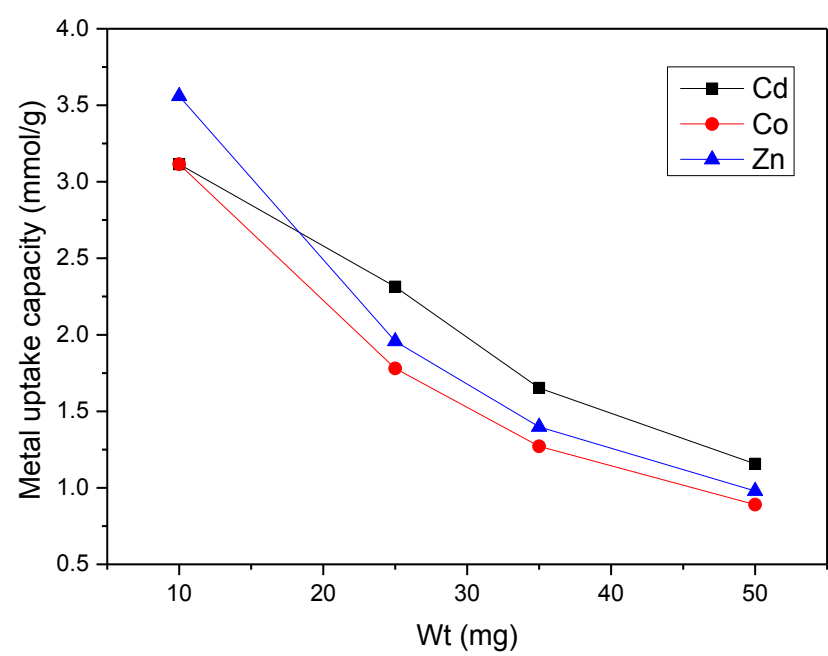

Figure 8: Effect of weight of SCMNPs on metal uptake capacity of $\mathrm{Cd}(\mathrm{II}), \mathrm{Co}(\mathrm{II})$, and $\mathrm{Zn}(\mathrm{II})$.

$\mathrm{mmol} \mathrm{g} \mathrm{g}^{-1}, \mathrm{k}=0.40 \mathrm{~g} \mathrm{mmol}^{-1} \mathrm{~min}^{-1}$ for $\mathrm{Cd}(\mathrm{II}), v_{o}=$ $0.952 \mathrm{mmol} \mathrm{g}^{-1} \mathrm{~min}^{-1}, \mathrm{q}_{\mathrm{e}}=2.080 \mathrm{mmol} \mathrm{g}^{-1}, \mathrm{k}=0.22 \mathrm{~g}$ $\mathrm{mmol}^{-1} \mathrm{~min}^{-1}$ for $\mathrm{Zn}(\mathrm{II})$, and $v_{o}=1.153 \mathrm{mmol} \mathrm{g}^{-1} \mathrm{~min}^{-1}$, $\mathrm{q}_{\mathrm{e}}=1.840 \mathrm{mmol} \mathrm{g}^{-1}$, and $\mathrm{k}=0.34 \mathrm{~g} \mathrm{mmol}^{-1} \mathrm{~min}^{-1}$ for Co(II). Calculated values of qe (2.380, 2.080, 1.840

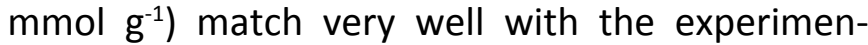
tal values $\left(2.314,1.958,1.780 \mathrm{mmol} \mathrm{g}^{-1}\right)$ and the correlation coefficient is above 0.99 for the three metals, respectively. All these data confirm that this model can be applied for the entire adsorption process and corroborate the sorption of the three metals on the surface of SCMNPs.

Effect of weight of nano-adsorbent: The effect of SCMNPs amount was also studied to illustrate the relationship between $\mathrm{Cd}(\mathrm{II}), \mathrm{Zn}(\mathrm{II})$, and $\mathrm{Co}(\mathrm{II})$ adsorption and mass of SCMNPs, Figure 8. The weight of SCMNPs was varied from $10 \mathrm{mg}$ to 50 $\mathrm{mg}$ keeping all the other experimental variables at the optimum values. As weights of nano-adsorbent increase, the number of available adsorption sites increase until it reach saturation at $25 \mathrm{mg}$. Metal uptake capacities with $25 \mathrm{mg}$ dosage of nano-adsorbent (optimum weight) for $\mathrm{Cd}(\mathrm{II}), \mathrm{Zn}(\mathrm{II})$, and Co(II) were 2.314, 1.952, and $1.870 \mathrm{mmol} / \mathrm{g}$, respectively. This can be explained with the increase of surface area and the availability of the binding sites. At higher adsorbent dosage, increased number of adsorption sites enhances the uptake of metal ions. On the other hand, the adsorption capacity decreased with the increase in adsorbent mass, this behavior could be explained by the high ratio of the active sites relative to the metal ions,

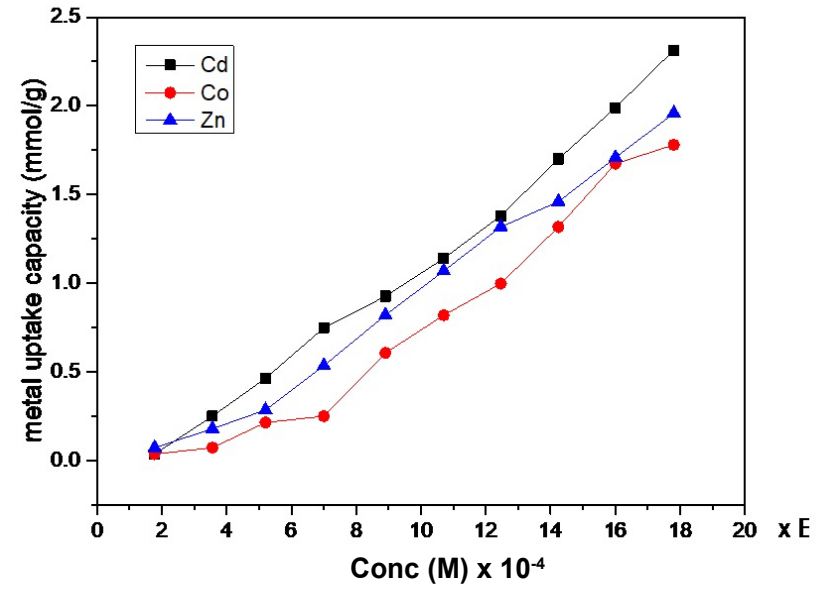

Figure 9: Effect of concentration of the solution on metal uptake capacity of $\mathrm{Cd}(\mathrm{II}), \mathrm{Co}(\mathrm{II})$, and $\mathrm{Zn}(\mathrm{II})$ using SCMNPs.

which decreases the saturation of the active sites. In addition, the agglomeration of the nano-adsorbent particles (because of London interaction) at high dosage might also have a negative effect on the adsorption capacity $[10,26]$.

Effect of metal ion concentration: The effect of concentration of metal ion on metal uptake was studied at concentrations from $2 \times 10^{-4}$ to $2 \times 10^{-3}$ $\mathrm{M}$ with nano-adsorbent weight of $25 \mathrm{mg}, \mathrm{pH} 5.0$ for $\mathrm{Cd}(\mathrm{II})$ and $\mathrm{Co}(\mathrm{II})$, and 6.0 for $\mathrm{Zn}(\mathrm{II})$, and contact time of $10 \mathrm{~min}$. At lower metal concentration, the ratio of number of moles of metal ion in solution to the available surface area is low and hence binding is independent of initial concentration. At higher concentration the available sites for binding is less and hence metal removal is dependent on the initial concentration. The results showed that metal uptake capacity increased with increasing of concentration of metal ion as shown in Figure 9. This indicates that metal uptake is highly dependent on the metal ion initial concentration.

The adsorption isotherms of $\mathrm{Cd}(\mathrm{II}), \mathrm{Zn}(\mathrm{II})$, and Co(II) could be analyzed by models given by Langmuir and Freundlich. The equation of Langmuir is applied to monolayer sorption with a completely homogeneous surface and a finite number of identical sites, is often applicable for a negligible interaction between the adsorbed molecules.

$$
\frac{\mathrm{C}_{\mathrm{e}}}{\mathrm{q}_{\mathrm{e}}}=\frac{\mathrm{C}_{\mathrm{e}}}{\mathrm{q}_{\mathrm{m}}}+\frac{\mathrm{K}_{\mathrm{ads}}}{\mathrm{q}_{\mathrm{m}}}
$$

Where, $C_{e}$ and $q_{e}$ represent the equilibrium concentrations of the adsorbate in the liquid and ad- 

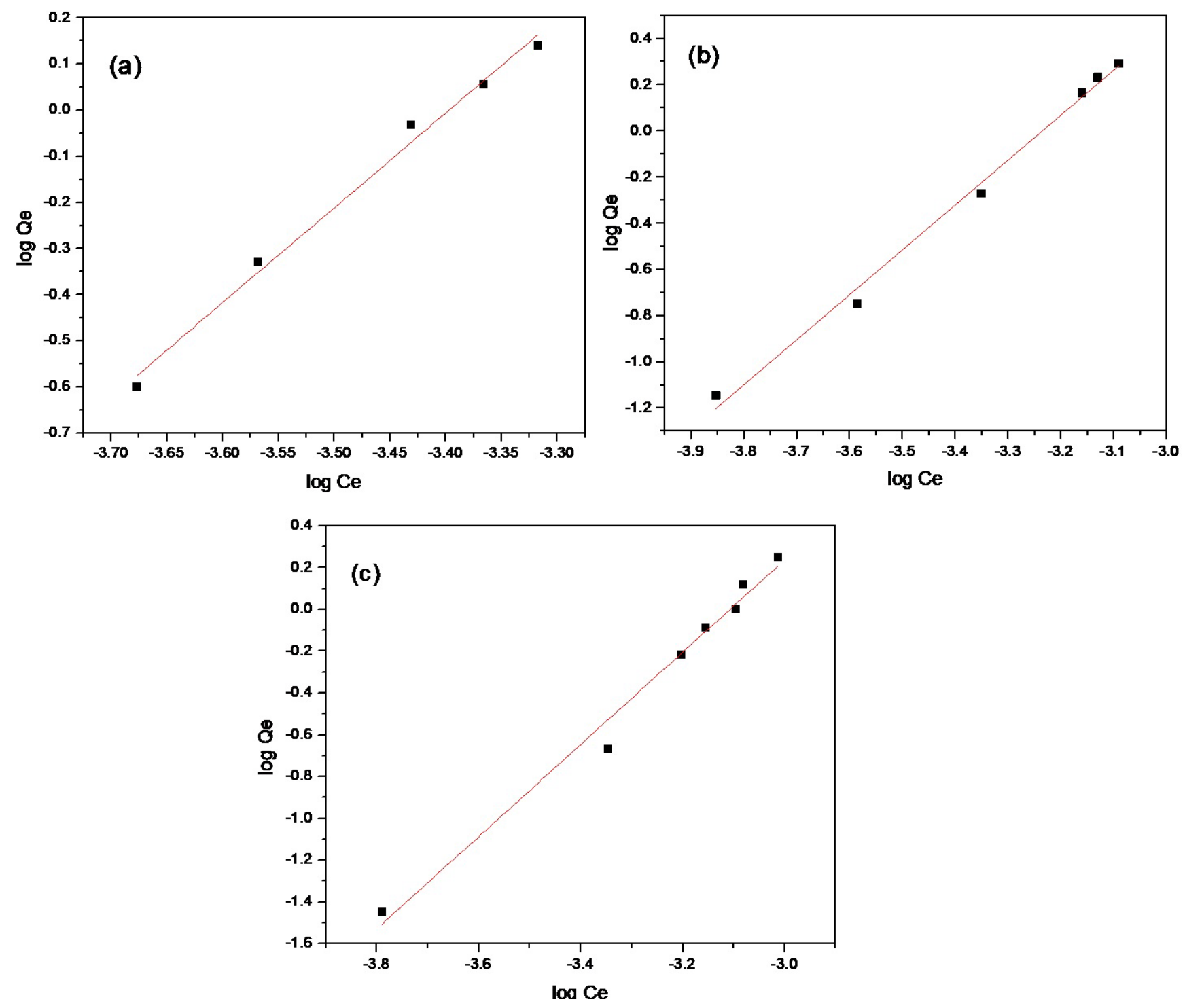

Figure 10: Freundlich plot for adsorption capacity of a) Cd(II); b) Zn(II); and c) Co(II) using SCMNPs.

sorbed phase in $\mathrm{mmol} \mathrm{ml}^{-1}$ and $\mathrm{mmol} \mathrm{g}^{-1}$, respectively. $\mathrm{q}_{\mathrm{m}}$ and $\mathrm{k}_{\text {ads }}$ are Langmuir constants which are related to the maximum sorption capacity $(\mathrm{mmol}$ $\left.\mathrm{g}^{-1}\right)$ and the affinity of binding sites $\left(\mathrm{ml} \mathrm{mmol}^{-1}\right)$, respectively, and can be calculated from the intercept (kads/qm), and slope (1/qm) of the linear plot, $\mathrm{C}_{\mathrm{e}} / \mathrm{q}_{\mathrm{e}}$ vs. $\mathrm{C}_{\mathrm{e}}$.

The Freundlich equation was first used to describe gas phase adsorption and solute adsorption. In 1909, German scientist Freundlich proved an empirical relationship between the amount of gas adsorbed by a unit mass of solid adsorbent and pressure at a particular temperature. The Freundlich isotherm model assumes neither limited levels of sorption nor homogeneous site energies.

Freundlich equation in the linear form identified as follows:

$$
\mathrm{q}_{\mathrm{e}}=\mathrm{k}_{\mathrm{f}} \mathrm{C}_{\mathrm{e}}{ }^{1 \ln }
$$

By taking log the equation becomes:

$$
\log \mathrm{q}_{\mathrm{e}}=\log \mathrm{k}_{\mathrm{f}}+\frac{1}{\mathrm{n}} \log \mathrm{C}_{\mathrm{e}}
$$

Here, $k_{f}$ and $n$ are Freundlich constants, they are indicators of the sorption capacity and sorption intensity, respectively by drawing a plot of $\log q_{e} v s$. $\log C_{e^{\prime}}$ the plot has slop with a value of $1 / n$, and an intercept of $\log \mathrm{k}_{\mathrm{f}}$, Figure 10. Values of $\mathrm{k}_{\mathrm{f}}$ were $(9.33$ $\times 106,1.90 \times 106,7.07 \times 106)$, values of $n$ were ( $0.48,0.51,0.45)$, values of $R^{2}$ were $(0.989,0.992$, 0.982 ) for $\mathrm{Cd}(\mathrm{II}), \mathrm{Zn}(\mathrm{II})$, and $\mathrm{Co}(\mathrm{II})$ respectively. It was observed from the isotherm and the correlation coefficient that the fit is better with the Freundlich model.

\section{Stability and Reusability of the nano-adsorbent}




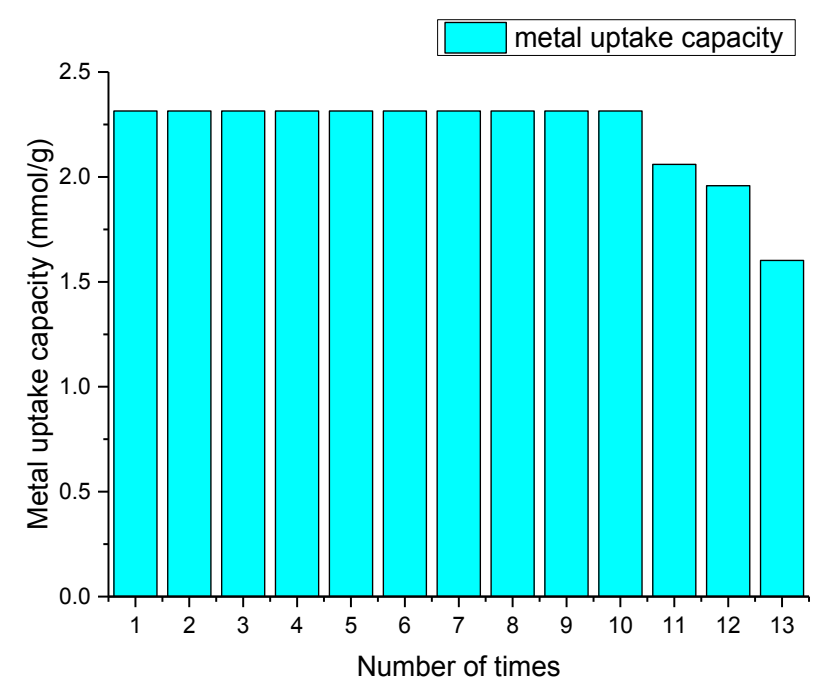

Figure 11: Reusability of SCMNPs.

The study of the effect of acidic medium on SCMNPs represents a significant practical application point to show the stability of this nano-adsorbent. SCMNPs were found to have experienced pronounced stability under the effect of acidic medium even after a long contact time. In practical experiment, we found that the hydrolysis percentages were $0.0 \%, 1.5 \%$ and $4.6 \%$ when the phase was treated with concentrations of $0.1,0.3$ and $0.5 \mathrm{M}$ of hydrochloric acid, respectively. The percentage of the hydrolysis when it was impregnated overnight was equal to $4.6 \%$.

For the possibility of reusing SCMNPs, the batch recycling process was repeated till decreasing of metal capacity occurred. SCMNPs exhibited good stability with a very slow decline in metal capacity as the number of experimental cycles increased. The value of the metal capacity has remained constant for ten times of recycling. By comparing to those in the first cycle, metal uptake capacity in the eleventh cycle decreased by only $10.97 \%$, and the amount of decline in the twelfth and thirteenth times was by $12.70 \%$ and $15.38 \%$, respectively, Figure 11. It was proved that SCMNPs has the ability of reusing with ease of regeneration for multiple cycles without any appreciable loss in its activity.

\section{Removal of Cd(II) ion from real water samples by SCMNPs using batch technique}

To estimate the applicability of SCMNPs, water from natural sources (groundwater, seawater, Nile River water, and drinking tap water samples) has been analyzed. From the previous batch study it was found that, $\mathrm{Cd}(\mathrm{II})$ is considered to have the
Table 1: Recovery of Cd(II) spiked real water samples with SCMNPs using batch technique (Weight of SCMNPs $=25.0$ $\mathrm{mg}$, and $\mathrm{pH}=5.0$ )

\begin{tabular}{|l|l|l|}
\hline Water sample & $\mathbf{C d}(\mathbf{I I})$ ion Spiked (ppm) & \% Extraction \\
\hline \multirow{3}{*}{ Tap water } & 150 & $97.5 \pm 0.20$ \\
\cline { 2 - 3 } & 100 & $97.2 \pm 0.10$ \\
\cline { 2 - 3 } Ground water & 50 & $96.0 \pm 0.10$ \\
\hline \multirow{3}{*}{ Nile River water } & 150 & $97.0 \pm 0.05$ \\
\cline { 2 - 3 } & 100 & $96.3 \pm 0.10$ \\
\cline { 2 - 3 } & 150 & $95.0 \pm 0.20$ \\
\cline { 2 - 3 } & 100 & $97.3 \pm 0.10$ \\
\hline Sea water & 50 & $97.0 \pm 0.20$ \\
\hline & 150 & $96.4 \pm 0.10$ \\
\cline { 2 - 3 } & 100 & $96.4 \pm 0.05$ \\
\hline & 50 & $95.5 \pm 0.20$ \\
\hline
\end{tabular}

highest metal uptake capacity value, therefore it was selected to test the feasibility of applying SCMNPs to purify natural water samples after spiking with its different concentrations $(50,100,150$ ppm). The results obtained after the third run of batch technique are included in Table 1. A good recovery values were achieved that ranged from $95.0 \%$ to $97.5 \%$.

\section{Comparison of adsorption capacity, contact time, and particle size of SCMNPs with other adsorbents in removing heavy metal ions}

The advantages of the synthesized SCMNPs in comparison with other reported works were compiled in Table 2, Table 3 and Table 4. It includes the high efficiency of SCMNPs with respect to time required for equilibrium, and size of the adsorbent. SCMNPs have produced outstanding results in removing $\mathrm{Cd}(\mathrm{II}), \mathrm{Zn}(\mathrm{II})$ and $\mathrm{Co}(\mathrm{II})$ ions from aqueous solutions comparing with recently used adsorbents. From these tables we can conclude that SCMNPs can remove heavy metals efficiently with high values of metal uptake capacity $(260.11,128.03$, $104.89 \mathrm{mg} / \mathrm{g}$ for Cd(II), Zn(II), and Co(II) respectively), very short contact time(10 $\mathrm{min})$, and with very small nanosized particles (11.7-24.81 nm).

\section{Conclusion}

- SCMNPs have been used to remove some toxic heavy metal ions with high metal uptake capacity values. This magnetic nano-adsorbent was prepared using microwave technique that has the economic and benign advantages of simplic- 
Table 2: Comparison of the adsorption capacity, contact time, and particle size of SCMNPs with similar adsorbents in removing of $\mathrm{Cd}(\mathrm{II})$.

\begin{tabular}{|c|c|c|c|c|}
\hline Adsorbent & Adsorption capacity $\mathrm{mg} / \mathrm{g}$ & Contact time & Particle size of adsorbent & Ref. \\
\hline Aluminosilicates & $42.7-57.9$ & $20 \mathrm{~h}$ & $0.2-2.18 \mathrm{~mm}$ & {$[27]$} \\
\hline Calcite & 18.52 & $10 \min$ & 100 mesh & [28] \\
\hline Chromite mine over burden & 22.47 & $30 \mathrm{~min}$ & - & [29] \\
\hline Iron ore slime & 34.75 & - & - & {$[30]$} \\
\hline Low grade manganese ore & 59.17 & $7 \mathrm{~h}$ & $0.152 \mathrm{~mm}$ & [31] \\
\hline Manganese nodule residue & 21.2 & $1 \mathrm{~h}$ & $\begin{array}{l}150 \text { Mesh B.S.S passed } \\
\text { Particles }(100 \%<-100 \mu \mathrm{m})\end{array}$ & [32] \\
\hline Nickel laterite (high iron) & 13.2 & $1 \mathrm{~h}$ & $100 \%<100 \mu \mathrm{m}(-150$ mesh $)$ & [33] \\
\hline Nickel laterite (low iron) & 11 & $1 \mathrm{~h}$ & $100 \%<100 \mu \mathrm{m}(-150$ mesh $)$ & [33] \\
\hline Nickel, leaching residue & 25 & - & Smaller than $20 \mu \mathrm{m}$ & [34] \\
\hline Palygorskite & 4.54 & $1 \mathrm{~h}$ & 200 mesh & {$[35]$} \\
\hline Perlite & 0.64 & $6 \mathrm{~h}$ & $1.7 \mathrm{~mm}$ & [36] \\
\hline Red bauxite & 38.77 & - & - & {$[32]$} \\
\hline Silica, mesoporous & $111.3 \pm 3.3$ & $1 \mathrm{~h}$ & $2-50 \mathrm{~nm}$ & {$[37]$} \\
\hline Silicate MCM-41, mesoporous & 100 & $1 \mathrm{~h}$ & $2-50 \mathrm{~nm}$ & [37] \\
\hline Oxidized MWCNTs & 25.7 & $45 \mathrm{~min}$ & $\begin{array}{l}\text { Outer diameters }=20-30 \mathrm{~nm} \\
\text { Inner diameters }=5-10 \mathrm{~nm} \\
\text { Length between } 5 \text { and } 200 \mu \mathrm{m}\end{array}$ & [38] \\
\hline SCMNPs & 260.11 & $10 \min$ & $11.7-24.81 \mathrm{~nm}$ & Current study \\
\hline
\end{tabular}

Table 3: Comparison of the adsorption capacity, contact time, and particle size of SCMNPs with similar adsorbents in removing of $\mathrm{Zn}(\mathrm{II})$.

\begin{tabular}{|c|c|c|c|c|}
\hline Adsorbent & $\begin{array}{l}\text { Adsorption } \\
\text { capacity } \mathrm{mg} / \mathrm{g}\end{array}$ & $\begin{array}{l}\text { Contact } \\
\text { time }\end{array}$ & $\begin{array}{l}\text { Particle size of } \\
\text { adsorbent }\end{array}$ & Reference \\
\hline Bentonite & 52.91 & $15 \mathrm{~min}$ & $0.160-0.630 \mathrm{~mm}$ & [39] \\
\hline Activated alumina & 13.69 & $30 \mathrm{~min}$ & - & [40] \\
\hline Natural zeolite & 2.21 & $40 \mathrm{~min}$ & $1-3 \mathrm{~mm}$ & [41] \\
\hline Bagasse fly ash modified activated carbon $\left(10^{\circ} \mathrm{C}\right)$ & 24.06 & $75 \min$ & $200-250 \mu \mathrm{m}$ & [42] \\
\hline Bagasse modified activated carbon $\left(25^{\circ} \mathrm{C}\right)$ & 31.11 & $12 \mathrm{~h}$ & $<325$ mesh & [43] \\
\hline Bagasse modified activated carbon $\left(40^{\circ} \mathrm{C}\right)$ & 54 & $12 \mathrm{~h}$ & $<325$ mesh & [43] \\
\hline Coal fly ash unmodified $\left(30-60^{\circ} \mathrm{C}\right)$ & $6.5-13.3$ & $45 \mathrm{~min}$ & $47.9 \mu \mathrm{m}$ & {$[44]$} \\
\hline Fe impregnated fly ash modified $\mathrm{FeCl}_{3}\left(30-60^{\circ} \mathrm{C}\right)$ & $7.5-15.5$ & $45 \mathrm{~min}$ & $47.9 \mu \mathrm{m}$ & [44] \\
\hline $\mathrm{Al}$ impregnated fly ash modified $\mathrm{Al}\left(\mathrm{NO}_{3}\right)_{3}\left(30-60{ }^{\circ} \mathrm{C}\right)$ & $7.0-15.4$ & $45 \min$ & $47.9 \mu \mathrm{m}$ & {$[44]$} \\
\hline SCMNPs & 128.03 & $10 \min$ & $11.7-24.81 \mathrm{~nm}$ & (current study) \\
\hline
\end{tabular}

ity, rapidity and free organic solvents.

- The experimental controlling parameters affecting the metal ions uptake were studied and optimized and the results confirmed the heavily dependence on reaction $\mathrm{pH}$, adsorbent dosage, contact time and metal ions concentrations.

- Adsorption isotherm study revealed that the adsorption process was fitted well with Freundlich model. In addition, it was found that the pseudo-second-order rate model described the kinetic data more accurately.

- Stability of SCMNPs was investigated with provided excellent results. Also, regeneration studies confirmed the possibility of SCMNPs reuse without significant decrease in its efficiency.

- The SCMNPs were applied to purify different natural water samples and gave high recovery efficiencies.

- SCMNPs is considered as a promising magnetic 
Table 4: Comparison of the adsorption capacity, contact time, and particle size of SCMNPs with similar adsorbents in removing of $\mathrm{Co}(\mathrm{II})$.

\begin{tabular}{|c|c|c|c|c|}
\hline Adsorbent & $\begin{array}{l}\text { Adsorption } \\
\text { capacity } \mathrm{mg} / \mathrm{g}\end{array}$ & Contact time & Particle size of adsorbent & Reference \\
\hline Al-pillared bentonite clay & 38.6 & $24 \mathrm{~h}$ & $-80+230$ & [45] \\
\hline Kaolinite & 0.919 & $2 \mathrm{~h}$ & -200 mesh & [46] \\
\hline Coir pith & 12.82 & $2 \mathrm{~h}$ & $300-600 \mu \mathrm{m}$ & {$[47]$} \\
\hline Sulphurised activated carbon & 153.6 & $4 \mathrm{~h}$ & $-80+230$ mesh & [48] \\
\hline Almond green hull & 45.5 & $7 \mathrm{~min}$ & $<44 \mu \mathrm{m}$ & [49] \\
\hline PFB1 (fungal based biosorbent) & 190 & $24 \mathrm{~h}$ & --- & {$[50]$} \\
\hline Natural zeolites & 14.38 & $5.5 \mathrm{~h}$ & $63-106 \mu \mathrm{m}$ & [51] \\
\hline Synthetic hydroxyapatit & 20.19 & $24 \mathrm{~h}$ & -- & {$[52]$} \\
\hline EDTA-modified silica gel & 20 & $4 \mathrm{~h}$ & $40-63,63-200 \mu \mathrm{m}$ & [53] \\
\hline Lemon peelnano-adsorbent & 22 & $10 \mathrm{~h}$ & BSS 150-200 mesh & [14] \\
\hline Magnetic chitosan Nano-adsorbent & 27.5 & $1 \mathrm{~min}$ & $13.5 \mathrm{~nm}$ & {$[54]$} \\
\hline SCMNPS & 104.89 & $10 \min$ & $11.7-24.81 \mathrm{~nm}$ & (current study) \\
\hline
\end{tabular}

nano-adsorbent when modifying its surface with different organic compounds rich in functional groups for purposes to improve the process of removing the pollutants from aqueous medium. Really, this idea is currently being worked on in our lab.

\section{Acknowledgment}

The Chemistry Department in Faculty of Science Minia University is gratefully acknowledged for supporting this study.

\section{References}

1. Neyaz N, Siddiqui WA, Nair KK (2014) Application of surface functionalized iron oxide nanomaterials as a nanosorbents in extraction of toxic heavy metals from ground water: A review. International Journal of Environmental Sciences 4: 472-483.

2. Shen $Y$, Tang J, Nie ZH, Wang D, Ren Y, et al. (2009) Preparation and application of magnetic $\mathrm{Fe}_{3} \mathrm{O}_{4}$ nanoparticles for wastewater purification. Separation and Purification Technology 68: 312-319.

3. Jamali-Behnam F, Asghar Najafpoor A, Davoudi M, Rohani-Bastami T, Alidadi $\mathrm{H}$, et al. (2018) Adsorptive removal of arsenic from aqueous solutions using magnetite nanoparticles and silica-coated magnetite nanoparticles. Environmental Progress \& Sustainable Energy 37: 951-960.

4. Iranmanesh M, Hulliger J (2017) Magnetic separation: Its application in mining, waste purification, medicine, biochemistry and chemistry. Chem Soc Rev 46: 5925-5934.

5. Dash M (2013) Silica coated magnetite nanoparticles for removal of heavy metal ions from polluted waters.

6. Moliner-Martínez Y, Ribera A, Coronado E, Campíns-Falcó $P$ (2011) Preconcentration of emerging contaminants in environmental water samples by using silica supported $\mathrm{Fe}_{3} \mathrm{O}_{4}$ magnetic nanoparticles for improving mass detection in capillary liquid chromatography. Journal of Chromatography A 1218: 2276-2283.

7. Tahergorabi M, Esrafili A, Kermani A, Shirzad-Siboni $M$ (2016) Application of thiol-functionalized mesoporous silica-coated magnetite nanoparticles for the adsorption of heavy metals. Desalination and Water Treatment 57: 19834-19845.

8. Konate A, He X, Zhang Z, Ma Y, Zhang P, et al. (2017) Magnetic $\left(\mathrm{Fe}_{3} \mathrm{O}_{4}\right)$ nanoparticles reduce heavy metals uptake and mitigate their toxicity in wheat seedling. Sustainability 9: 790.

9. Ge F, Meng Li M, Ye H, Xiang Zhao B (2012) Effective removal of heavy metal ions $\mathrm{Cd}^{2+}, \mathrm{Zn}^{2+}, \mathrm{Pb}^{2+}, \mathrm{Cu}^{2+}$ from aqueous solution by polymer-modified magnetic nanoparticles. Journal of Hazardous Materials 211-212: 366-372.

10.Taha A, Shreadah MA, Ahmed AM, Heibab HF (2016) Multi-component adsorption of Pb (II), Cd (II), and $\mathrm{Ni}$ (II) onto Egyptian Na-activated bentonite; equilibrium, kinetics, thermodynamics, and application for seawater desalination. Journal of Environmental Chemical Engineering 4: 1166-1180.

11.Carlos L, Einschlag F, González M, Mártire D (2013) Applications of magnetite nanoparticles for heavy metal removal from wastewater. Waste Water-Treatment Technologies and Recent Analytical Developments 2013: 63-77. 
12.Zhou L, Gao C, Xu W (2010) Magnetic dendritic materials for highly efficient adsorption of dyes and drugs. ACS Appl Mater Interfaces 2: 1483-1491.

13.Veli S, Alyüz B (2007) Adsorption of copper and zinc from aqueous solutions by using natural clay. $J$ Hazard Mater 149: 226-233.

14.Bhatnagar A, Minocha A, Sillanpää M (2010) Adsorptive removal of cobalt from aqueous solution by utilizing lemon peel as biosorbent. Biochemical Engineering Journal 48: 181-186.

15.Johri N, Jacquillet G, Unwin R (2010) Heavy metal poisoning: the effects of cadmium on the kidney. Biometals 23: 783-792.

16. Barakat M (2011) New trends in removing heavy metals from industrial wastewater. Arabian Journal Of Chemistry 4: 361-377.

17. Lee D-W, Fatima H, Kim K-S (2018) Preparation of silica coated magnetic nanoparticles for bioseparation. J Nanosci Nanotechnol 18: 1414-1418.

18.Fajaroh F, Setyawan H, Nur A, Lenggoroc WI (2013) Thermal stability of silica-coated magnetite nanoparticles prepared by an electrochemical method. Advanced Powder Technology 24: 507-511.

19.Ahmed SA, Soliman EM (2013) Silica coated magnetic particles using microwave synthesis for removal of dyes from natural water samples: Synthesis, characterization, equilibrium, isotherm and kinetics studies. Applied surface science 284: 23-32.

20.Yamaura M, Camilo RL, Sampaio LC, Macêdoc MA, Nakamura M, et al. (2004) Preparation and characterization of (3-aminopropyl)triethoxysilane-coated magnetite nanoparticles. Journal of Magnetism and Magnetic Materials 279: 210-217.

21. Heiba HF, Taha AA, Mostafa AR, Mohamed LA, Fahmy MA (2020) Preparation and characterization of novel mesoporous chitin blended $\mathrm{MoO}_{3}$-montmorillonite nanocomposite for $\mathrm{Cu}$ (II) and $\mathrm{Pb}$ (II) immobilization. Int J Biol Macromol 152: 554-566.

22.Almeida R, Guiton T, Pantano CG (1990) Characterization of silica gels by infrared reflection spectroscopy. Journal of Non-Crystalline Solids 121: 193-197.

23.Bagheri $H$, Afkhami A, Saber-Tehrani M, Khoshsafar $H$ (2012) Preparation and characterization of magnetic nanocomposite of Schiff base/silica/magnetite as a preconcentration phase for the trace determination of heavy metal ions in water, food and biological samples using atomic absorption spectrometry. Talanta 97: 87-95.

24.Rengaraj S, Yeon K-H, Moon S-H (2001) Removal of chromium from water and wastewater by ion exchange resins. J Hazard Mater 87: 273-287.

25. Heiba HF, Taha AA, Mostafa AR, Mohamed LA, Fahmy MA (2018) Synthesis and characterization of $\mathrm{CMC} / \mathrm{MMT}$ nanocomposite for $\mathrm{Cu}^{2+}$ sequestration in wastewater treatment. Korean J Chem Eng 35: 18441853.

26.Taha AA, Shreadah MA, Heiba HF, Ahmed AM (2017) Validity of Egyptian Na-montmorillonite for adsorption of $\mathrm{Pb}^{2+}, \mathrm{Cd}^{2+}$ and $\mathrm{Ni}^{2+}$ under acidic conditions: Characterization, isotherm, kinetics, thermodynamics and application study. Asia-Pacific Journal of Chemical Engineering 12: 292-306.

27.Davila-Rangel J, Solache-Ríos M, Badillo-Almaraz V (2005) Comparison of three Mexican aluminosilicates for the sorption of cadmium. Journal of Radioanalytical and Nuclear Chemistry 267: 139-145.

28. Guzel R, Aydin F, Tegin I, Ziyadanogullari R (2007) Removal of cadmium and lead from aqueous solution by calcite. Polish Journal of Environmental Studies 16: 467-471.

29.Mohapatra M, Anand S (2007) Studies on sorption of Cd (II) on Tata chromite mine overburden. Journal of Hazardous Materials 148: 553-559.

30. Mohapatra M, Rout k, Mohapatra BK, Anand S (2009) Sorption behavior of $\mathrm{Pb}$ (II) and Cd (II) on iron ore slime and characterization of metal ion loaded sorbent. Journal of Hazardous Materials 166: 15061513.

31. Mohapatra M, Khatun S, Anand S (2008) Adsorption of heavy metal ions on manganese nodule-A comparative study. Pollution Res 25: 563-568.

32. Rout K, Mohapatra M, Mohapatra BK, Anand S (2009) Pb (II), Cd (II) and Zn (II) adsorption on low grade manganese ore. International Journal of Engineering, Science and Technology 1: 106-122.

33. Mohapatra M, Anand S (2007) Cd (II) adsorption on high iron containing lateritic ore of Orissa. Indian Journal of Environmental Protection 27: 509.

34.Václavíková M, Gallios GP (2006) Removal of cadmium, zinc, lead and copper by sorption on leaching residue from nickel production. Acta Montanistica Slovaca 11: 393-396.

35.Álvarez-Ayuso E, García-Sánchez A (2007) Removal of cadmium from aqueous solutions by palygorskite. Journal of Hazardous Materials 147: 594-600.

36. Mathialagan T, Viraraghavan T (2002) Adsorption of cadmium from aqueous solutions by perlite. Journal of Hazardous Materials 94: 291-303. 
37. Syunichi Oshima, Jilska M Perera, Kathy A Northcott, Hisao Kokusen, Geoffrey W Stevens, et al. (2006) Adsorption behavior of cadmium (II) and lead (II) on mesoporous silicate MCM-41. Separation Science and Technology 41: 1635-1643.

38.Vuković GD, Marinković AD, Čolić M, Ristić MĐ, Aleksić R, et al. (2010) Removal of cadmium from aqueous solutions by oxidized and ethylenediamine-functionalized multi-walled carbon nanotubes. Chemical Engineering Journal 157: 238-248.

39. Mellah A, Chegrouche $S$ (1997) The removal of zinc from aqueous solutions by natural bentonite. Water Research 31: 621-629.

40. Maather F Sawalha, Jose R Peralta-Videa, Jaime Romero-González, Maria Duarte-Gardea, Jorge L Gardea-Torresdey (2007) Thermodynamic and isotherm studies of the biosorption of $\mathrm{Cu}(\mathrm{II}), \mathrm{Pb}$ (II), and $\mathrm{Zn}$ (II) by leaves of saltbush (Atriplex canescens). The Journal of Chemical Thermodynamics 39: 488-492.

41. Motsi T, Rowson N, Simmons M (2009) Adsorption of heavy metals from acid mine drainage by natural zeolite. International Journal of Mineral Processing 92: 42-48.

42.Gupta VK, Ali I (2000) Utilisation of bagasse fly ash (a sugar industry waste) for the removal of copper and zinc from wastewater. Separation and Purification Technology 18: 131-140.

43. Mohan D, Singh KP (2002) Single-and multi-component adsorption of cadmium and zinc using activated carbon derived from bagasse-an agricultural waste. Water Research 36: 2304-2318.

44.Banerjee S, Jayaram R, Joshi M (2003) Removal of nickel(II) and zinc(II) from wastewater using fly ash and impregnated fly ash. Separation Science and Technology 38: 1015-1032.

45. Manohar D, Noeline B, Anirudhan T (2006) Adsorption performance of Al-pillared bentonite clay for the removal of cobalt(II) from aqueous phase. Applied Clay Science 31: 194-206.
46.Yavuz Ö, Altunkaynak Y, Güzel F (2003) Removal of copper, nickel, cobalt and manganese from aqueous solution by kaolinite. Water Research 37: 948-952.

47. Harshala Parab, Shreeram Joshi, Niyoti Shenoy, Arvind Lali, Sarma US, et al. (2006) Determination of kinetic and equilibrium parameters of the batch adsorption of $\mathrm{Co}(\mathrm{II}), \mathrm{Cr}(\mathrm{III})$ and $\mathrm{Ni}(\mathrm{II})$ onto coir pith. Process Biochemistry 41: 609-615.

48. Krishnan KA, Anirudhan T (2008) Kinetic and equilibrium modelling of cobalt(II) adsorption onto bagasse pith based sulphurised activated carbon. Chemical Engineering Journal 137: 257-264.

49.Ahmadpour A, Tahmasbic M, Bastami TR, Besharati JA (2009) Rapid removal of cobalt ion from aqueous solutions by almond green hull. Journal of Hazardous Materials 166: 925-930.

50.Suhasini I, Sriram G, Asolekar SR, Sureshkumar GK (1999) Biosorptive removal and recovery of cobalt from aqueous systems. Process Biochemistry 34: 239-247.

51.Erdem E, Karapinar N, Donat R (2004) The removal of heavy metal cations by natural zeolites. Journal of Colloid and Interface Science 280: 309-314.

52.Smičiklas I, Dimovic S, Plecas I, Mitric M (2006) Removal of $\mathrm{Co}^{2+}$ from aqueous solutions by hydroxyapatite. Water Research 40: 2267-2274.

53. Eveliina Repo, Tonni Agustiono Kurniawan, Jolanta K Warchol, Mika ET Sillanpää (2009) Removal of Co(II) and $\mathrm{Ni}(\mathrm{II})$ ions from contaminated water using silica gel functionalized with EDTA and/or DTPA as chelating agents. Journal of Hazardous Materials 171: 1071-1080.

54.Chang Y-C, Chang S-W, Chen D-H (2006) Magnetic chitosan nanoparticles: Studies on chitosan binding and adsorption of $\mathrm{Co}$ (II) ions. Reactive and Functional Polymers 66: 335-341. 
(a) co-precipitation synthesis

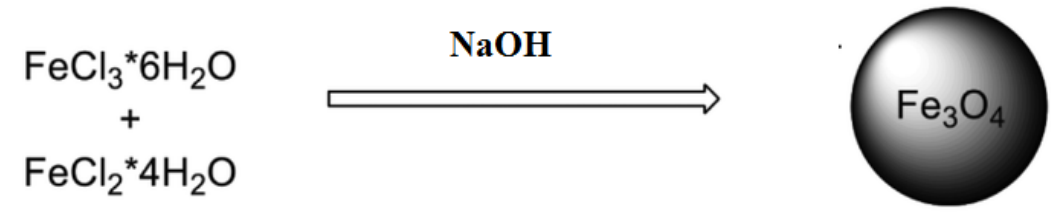

Fe3O4 NPs

(b) microwave synthesis

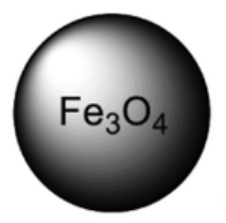

Fe3O4 NPs

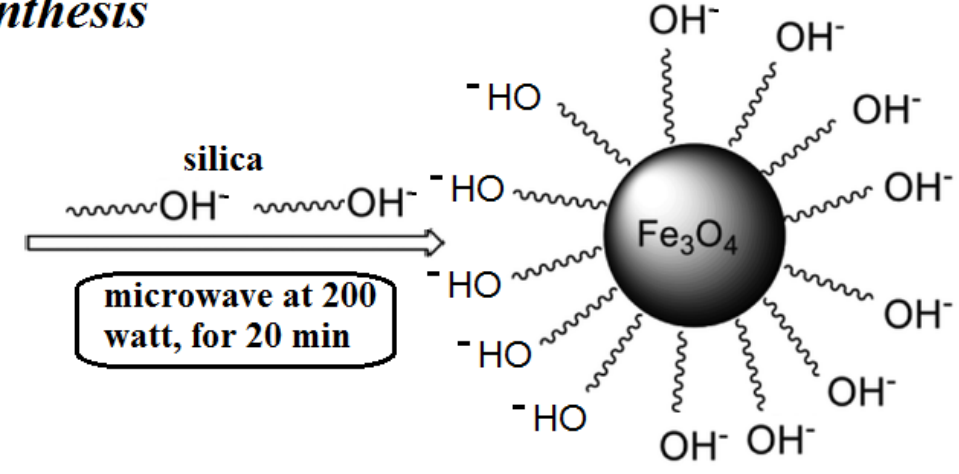

SCMNPs

Scheme 1: Co-precipitation and microwave synthesis of SCMNPs. 